Volume 18 Number 1 June 2018.p.161-184

https://doi.org/10.30603/au.v18i1.316

\title{
An Elaborative Study On The Perception And Prevention Of The East Java's PTKIN Students About Proxy War
}

\author{
Iffatin Nur \& Munarji \\ The State Islamic Institute (IAIN) of Tulungagung
}

\begin{abstract}
As a new form of warfare, proxy war does not require arm contacts to invade a country. Through conspiracy, propaganda and the establishment, a country may be ravaged by other more powerful countries. As a developing country with abundant natural and human resources, Indonesia becomes an easy target for super power countries to launch their proxy wars. Therefore anticipatory measures to stem the dangers of a proxy war are needed. This study used a qualitative approach through interviews. The conclusions of this study are: (1) the perceptions ofthe East Java's PTKIN students on the issue of proxy war. First, in terms of its notion, there are four perceptions about proxy war. Two of them do not have compatibility with the theory of proxy war. Second, the perception of the dangers of proxy war in which there are two perceptions: 1) that the proxy war is absolutely very dangerous and 2) that it cannot be justified simply to be dangerous or not before its victims arise. Third, in the constellation of proxy war, Indonesia has been for a long time in its vortex as Indonesia is a country with abundant natural and human resources.
\end{abstract}

\begin{abstract}
Abstrak
Sebagai bentuk perang baru, perang proksi tidak memerlukan kontak senjata untuk menyerang suatu negara. Melalui konspirasi, propaganda dan pendirian, suatu negara dapat dirusak oleh negara-negara lain yang lebih kuat. Sebagai negara berkembang dengan sumber daya alam dan manusia yang melimpah, Indonesia menjadi sasaran empuk bagi negara-negara super power untuk meluncurkan perang proksi mereka. Karena itu diperlukan langkah antisipatif untuk membendung bahaya perang proxy. Penelitian ini menggunakan pendekatan kualitatif melalui wawancara. Kesimpulan dari penelitian ini adalah: (1) persepsi siswa PTKIN Jawa Timur tentang masalah perang proxy. Pertama, dalam hal gagasannya, ada empat persepsi tentang perang proksi. Dua dari mereka tidak memiliki kompatibilitas dengan teori perang proxy. Kedua, persepsi bahaya perang proksi di mana ada dua persepsi: 1) bahwa perang proksi benar-benar sangat berbahaya dan 2) tidak dapat dibenarkan hanya karena berbahaya atau tidak sebelum korbannya muncul. Ketiga, dalam konstelasi perang proksi, Indonesia telah lama berada di pusarannya karena Indonesia adalah negara dengan sumber daya alam dan manusia yang melimpah.
\end{abstract}

Keywords: elaborative, preventive, proxy war

Author correspondence

Email: iffaeltinury@gmail.com, munardji2013@gmail.com

Available online at http://journal.iaingorontalo.ac.id/index.php/au/index 


\section{A. Introduction}

Along with the development of technology, the nature and characteristics of war at present has shifted from a conventional war to a proxyone or an asymmetric and hybrid war. ${ }^{1}$ proxy war is defined as a confrontation between the two major powers by using replacem ent players to avoid a direct confrontation based on a reason to reduce the risk of a direct conflict impacting a fatal destruction. Usually a third party acting as a substitute is a small country or a non-state actor that can be in the form of NGOs, CBOs, community groups or individuals. In a proxy war, it is unable to identify clearly who is ally or enemy since the enemy usually controls non-stateactors from afar.

The proxy war has taken place in Indonesia in various forms such as separatist movements, mass demonstrations, drug trafficking, clashes between groups in societies and miscellaneous regulatory system (the government's policies ridden by foreign interests, e.g.laws on minerals, forestry, investment, and so on). The separation of East Timor from Indonesia starting from an armed uprising, diplomatic struggle, until the advent of the referendum, is a real example of a proxy war. The East Timorese gap that appears to have oil and gas in pretty fantastic quantity is actually the logical reason behind it.Australia is very eager to possess great control on the content of oil in East Timorese gap by riding on human rights issues in which Australia called for the importance of selfdetermination for the people of East Timor. Then, through its diplomatic channels, Australia lobbied the UN to pass a Security Council's resolution in order to allow multinational forces under its leadership to enter the East Timorese territory based on humanitarian reasons which was to stop violence and restore peace. ${ }^{2}$ Indonesia as one of the equatorial countries with great potency of vegetation throughout the year and a variety of quite fantastic energy and natural resources will be the battleground of international interest through a proxy war. This is so since the fossil energy in the world, as reported by the British Petroleum (BP) in

\footnotetext{
${ }^{1}$ An asymmetrical war is a war between belligerents or warring parties in which their military power is very different. Meanwhile, the hybridswar is a war that combines the conventional and asymmetric warfare techniques, and information warfare to gain victory over the opponent. At the time when a party feels to have enough power, theconventional war is done to beat the opponent, when its condition is weak and the situation is less favorable, then the information and ideological war is used. See: ChrisLoveman,Assesing the phenomeon of proxy intervention,Journal of Conflict, Security and Development, issue 2-3, Oxford, UK: Routledge, 2002, p. 19.

2 Paul Cleary, Shake Down: Australia's Grab for Timor Oil, Australia: Allen and Unwin Publishing, 2007
} 
2013,would stay about 40 years which means that the world's energy will be exhausted by the year $2053 .^{3}$

In addition, the geopolitical position of Indonesia which is right in the middle of the countries of the Five Power Defense Arrangement (FPDA), - a defense cooperation agreement of the British Common wealth states -, bears a vulnerability that should be of serious concern. In the north, there are Malaysia and Singapore, while in the south lie Australia and New Zealand. At least three of these four countries had a history of less harmonious bilateral relations with Indonesia.

Anticipatory measures are, therefore, required so that the unity and sovereignty of the state of the Republic of Indonesia is not disintegrated by any proxy war attack.One of urgent anticipatory measures to be implemented is to prepare students who are in particular become social agents of change. Meanwhile, on the other hand, they are youths who are vulnerable from proxy war attacks through drugs, free sex, the demonstrations, the issues of radicalism, and others alike. Understanding the perception and preventive measures in addressing the proxy war is an important strategy in preparing them to face it.

\section{B. The Proxy War}

\section{The Term and History of Proxy War}

The term proxy waris less familiar compared to the term cold warwhich took place after the Second World War. Since it is a new term in warfare in this modern eraand there are not many experts studying about it, it is difficult to find a comprehensive definition of it. The Indonesian Army's Chief of Staff Gen. Gatot Nurmantyo defines proxy war as a confrontation between two major powers by using replacement players to avoid direct confrontation with the reasons for reducing the risk of conflicts resulting in fatal destruction. ${ }^{4}$

Although it is a new term, - even in the Second World War era it had not yet been familiar -, if we look more closely, proxy war, particularly in the West, is identifiable during the the Cold War between the Soviet bloc and the US bloc after the Second World War. It can be seen from the support of the East

\footnotetext{
3 The British Petroleum, BP Statistical Review of World Energy, Uckfield, UK : Pure Print Group Ltd., 2013.

${ }^{4}$ The definition of proxy war as described by Gen. GatotNurmantyo(was the Chief of the Indonesian Army's Strategic Reserve Command),in an article titled "MenghadapiProxy War", JawaPos, 29 March, 2014
} 
Germany to the Rote ArmeeFrajtion (RAF) to show its dislikeness against the West Germany by sparking conspiratorial steps; China supported the Khmer Rouge regime in the late 1970s when Vietnam invaded Cambodia to replace existing regime, and, the latest example is when Libya supported the Provisional Irish Republican Army with a variety of weaponry to resist the British colonialism. Libya who never likes the United Kingdom utilized a third party (i.e. the Provisional Irish Republican Army) and armed them to attack or make confrontations with the British troops. ${ }^{5}$

The proxy war does not just stuck on the constellation of the Cold War between the Soviet Union's and the United States' blocs.One obvious example about other interests which were involved rather than what seemed to be an effort to fight for democracy is a war took place in the People's Republic of Congo. The war involved eight African countries which were either pro or contra to the Kabila regime. But, with a closer look, what actually happenned in the conflict of war involving such many countries in Africa was due to the seizure of diamond mining which was dominated by Uganda and Rwanda.Both countries competed against each other and created an unstable condition to have control and power over the diamond mines that are so abundant in the black continent. 6

In this modern era, there is a serious threat of proxy war, namely terrorism. Terrorism becomes a justifiable scapegoat as a reason for one state to participate or even control another state's stability. Moreover, today there are many non-stateorganizationsthat have access to weapons so that terrorism have been made an alibi to global security threats in which eventually other states can enter into a particular state and take control of it. ${ }^{7}$ Furthermore, armed groups (terrorists) within a state can also be made as a tool or a third party (proxy) by other states to destroy a regime in that particular state. We can take the case of a civil war in the Middle East, precisely in Syria, as an example. Clearly, the rebels were financed and armed by the Saudi Arabia and

\footnotetext{
${ }^{5}$ Loveman, Assessing the phenomenon ..., p.33

${ }^{6}$ Erik Melander, Magnus Öberg, and Jonathan Hall, Are 'New Wars' More Atrocious? Battle Severity, Civilians Killed and Forced Migration Before and After the End of the Cold War, European Journal of International Relations, 15, 2009, p. 508

7 Daniel Byman, et al., Trends in outside support for insurgent movement, Santa Monica: RAND, 2001, p.19
} 
the United States while the Syrian government was supported by Iran and Russia.

Meanwhile, Brewer stated that terminologicallya proxy war is a conflict in which one party fights its adversary via another party rather than engaging that party in direct conflict.The emergence of proxy war is also through a process. ${ }^{8}$ First, the war takes place openly and each partydeclareswar and tries to subjugate its opponent. This is, according to Brewer, a form of a classical warfare. But, after going through the times, war involvesabsurd parties as the hallmark of a proxy war but with the same purpose which is to subdue their opponents.

Jon Abbink illustrates that the politics of proxy war resembles a chess game, but one in which the rules constantly seem to change. This shows the great complexity of proxy war as well as becomes a distinctive feature of the model of a war using proxy. ${ }^{9}$ He also explains that, those act asthe third party (proxy) is always co-opted with the party or the state that becomesthe actors of the proxy war and will usually be of an ethno-regional nature.

From the definitions put forward by Gen. Gatot Nurmantyo, Brewer, Jon Abbink and some understanding on history about the proxy war, it can be concluded that proxy war is a war that occurs when an opponent uses a third party instead of fighting each other directly. Governments sometimes used their power as a proxy, whereas non-state actors more commonly used violence, mercenaries, and other third parties. The use of a third party(i.e. $a$ proxy) is an important point that cannot be separated when discussing the proxy war.

Furthermore, the Indonesian Army's Chief of Staff explained that a proxy war isusually exploited by third parties. Those who act as substitutes(proxies)areusually small states, but sometimes they can also be in the form of non-state actors, such as NGOs, CBOs, community groups or individuals. Proxy is a lengthening arm of a state attempting to gain strategic interests but avoidinga direct involvement in a costly and bloody war. ${ }^{10}$

\footnotetext{
${ }^{8}$ Cecily G Brewer, Peril by Proxy: Negotiating Conflicts in East Africa, International Negotiation, 16, 2011, p. 138

${ }^{9}$ Jon Abbink, Ethiopia-Eritrea: Proxy Wars and Prospects of Peace in the Horn of Africa, Journal of Contemporary African Studies, 21, 2003, pp. 407- 409

10 Ibid.
} 


\section{The Forms and Characteristics of Proxy War}

As mentioned earlier, employing non-state armed actors as proxies (e.g. terrorists) is a very logical thing conducted by a state to subjugate others. This hypothesis can be justified because, according to JMR Woudenberg, proxy warfare is a very covert foreign policy option. ${ }^{11}$ With this covert nature then it is possible that a state intervenes in financing non-state armed actors. Such is undeniable since a state must have a political interest in its regional territory so much so that it does not hesitate to sacrifice other states for the betterment of its own. Such cases are often found in the history of the world's global politics, such as the conflict in Germany post the Cold War era, the conflict in Congo, and most recently is one in Syria that its political constellation had been discussed earlier.

Not just in the form of physical conflicts, in his thesis Woudenberg also explained that a proxy war could also be in the form of aids from richer states to poorer ones. However, rather than giving such aids to help or accelerate the growth of the recipient state's economy, it can also be made as a powerful controlling tool to a particular state. Based on the reason of giving technical assistance and alike, the donor states will always scrutiny the recipient states that receive their flows of money. ${ }^{12}$ Eventually, not only acting as a watchdog, the donor states often becomethe determinant of the direction and development of the recipient ones.

Meanwhile, when described further, a proxy war can be carried out by a more powerful state against a weaker one in the form of: 1) Making such state as its foreign market for its product, 2) Inhibiting thebuilding and development of a weaker state's human resources so they cannot compete in a global free market era, 3) Recruiting young people with indoctrination through educational and material facilities, so that they are willing to be their agents. Eventually when they become the future leaders of theirown country, they will be easily controlled by the foreigngovernment, 4) The foreign states will undertake massive investment in strategic industries, in order to dominate strategic industry sectors (oil and gas, mining, electricity, communications,

11 JMR Woundenberg, Used or Abused ? Armed Non-state Actors as Proxies,Master diss. Master Politicologie: Internationale Betrekkingen, International Military Security, 2011, p.7.

12 Ibid. 
satellite, Military Main Equipment Weapons System, Blue-chip Equity, etc.), 5) Trying to create regional and global free trade pacst, so that local products become supressed and destroyed, as well as penetrating, infiltrating, giving bribes and making collusion with members of the state's legislature so that the strategic legislation products will benefit them, 6) Creating a group/groups of terrorists, so that, - under the pretext of fighting and destroying the global terrorism -, a foreign country can freely and easily intimidate and interveneweaker ones, 7) Purchasing and controlling the mass media, both printed and electronic ones, to shape the public opinion to their favor as well astaking control over high-level communication technology industries, such as communications and reconnaissance satellites, in order to tap and monitor all state's elites' conversations, to monitor and be familiar with the locations of military power,and to find outboth natural and human resources, and8) Dividing and destroying younger generation of a country with drugs, promiscuity, consumer culture, and indolences. ${ }^{13}$

In his thesis Woudenbergalso states thatthere are at least four prominent characteristics of a proxy war which are: 1)there is an asymmetric relation between the patron state and the target actor in the first place. This is by far the most important characteristics of a proxy war, 2) the actor (a third party/a proxy) must have somewhat the same interests in the bigger power game played at the interstate level. It should be able to accommodate itself in the foreign policy goals of the patron state, 3) there should be a degree of support from the patron state, and 4) the proxy itself is an actor that operates in between the interstate and intrastate level, on a more transnational, regional scale. This is important considering that it will easily and freely carry out its missions but difficult to be discovered because of its mentioned position, and the public will blame the government when there is injustice. ${ }^{14}$

${ }^{13}$ The results of the scientific discussion organisedby the Indonesian National Resilience Institute (Lembaga Ketahanan Nasional), Jakarta, 19June, 2014

14 Woundenberg, Used or abused ?.., p.23 


\section{The Research's Findings}

From the findings of research that have been mentioned earlier and by analyzing the data obtained, there are several key points about the focus of questions in this study. The main ideas are as follows:

\section{General Understanding about War}

\section{a. General Definition of War}

In the perspective of the East Java's PTKIN students, represented by those of UIN of Sunan Ampel Surabaya, of IAIN of Tulungagung, and of STAIN of Kediri, the points of their understanding about war in general are: 1) a war is a dispute involving more than two persons / groups, 2) in a warfare, there must be an effort or actions to defeat one party's opponent, and 3) in a war, there will occur attacks done by one party to another with a purpose to defeat its opponent. The effects of this attacking each other will cause losses for both parties.

\section{b. Elements and Conditions of Occurrence of War}

In the view (perspective) of the East Java's PTKIN students, there are elements and conditions that lead an act to be called a war. The elements are: 1) the existence of a problem (a dispute), an opponent (an enemy), a purpose (purposes), media / tools to fight / attack and anaction (to attack / to bring down), 2) to say that the relevant parties have entered into a war both parties have at least two conditions, namely: an action to attack each other and there is something disputed, 3) however, not all wars must be done by direct physical / arms contacts.

\section{The Perception about Proxy War}

\section{a. The Understanding about Proxy War}

In the perspective of the East Java's PTKIN students, there are at least four perceptions on the understanding about proxy war, namely: 1) a proxy war is a war occurring without any direct physical / arms contacts but only involving a third party. The purpose of involving a third party is to make it more effective both in strategy and expenses incurred, 2) a proxy war is a form of warfare that does not involve direct physical combats (arm confrontation), but rather only uses the arguments as a medium, 3) a proxy war is defined as a form of war 
undertaken not by employing direct physical combats (arm confrontation), but by using the mass media or technology that is now increasingly flourishing, and 4) a proxy war is understood as a form of a third party's involvement in a particular war with the aim to end the war quickly.

\section{b. The Elements and Forms of Proxy War}

In the perspective of the East Java's PTKIN students, there are elements and forms of proxy war. The elements are: 1) Involving a third party, having a specific goal, there are losers, facilities / accesses and destroying the social and cultural order. 2) The forms and examples of a proxy war include drugs, alcohol, a flood of foreign (e.g. Chinese) products, and LGBT issues. 3) Another example of a proxy war is a war of words between artists with their haters.

\section{c. The Dangers of Proxy War}

In the perspective of the East Java's PTKIN students, a proxy war has harmful effects, namely: 1) it can cause a mental damage to the nation's young generation. Eventually the future generation will not be able to take benefits from the natural resources owned by Indonesia, 2) it can also threaten the security and stability of the country (i.e. Indonesia in this case). Having such condition, many new problems will arise and the people will also be deceived, 3) it also has an impact on human rights and economic issues. The freedom of human rights in the countries that become targets of proxy wars are most likely affected, whereas the sectors of economy will suffer a loss or at least be impaired. 4) Apart from the views that acknowledge negative impacts of proxy war, there are students who have a different view about the consequences of proxy war. According to the latter view, the dangers of proxy war cannot be justified simply whether they bring negative or positive impacts but rather they must be seen from which point of view. If it causes victims then it may be said that it is dangerous and threatens the lives of many people.

\section{d. Indonesia in the Constellation of Proxy War}

In the perspective of the East Java's PTKIN students, in the constellation of proxy war Indonesia has some important points 
regarding to its position and role as a country, namely: 1) Indonesia has entered into a proxy war since the Dutch colonial era. It was marked with various indications such as the entry of foreign cultures to Indonesia that eliminate the identity of this nation. The increasingly widespread drug trafficking and the latest case of the widespread LGBT issues that deprave the morals of this nation are also real facts that cannot be refuted. 2) Relating to the position of Indonesia in the constellation of proxy war, there are several views, which are: first, Indonesia isthe most disadvantaged country since the Indonesian people will be controlled and much influenced by foreigners without being able to think critically. Second, in addressing the position of Indonesia in the constellation of proxy war, there are two effects, positive and negative ones -, faced by Indonesia. Its positive effect is that Indonesia will be able to keep abreast of the era's development so that it will be more alert (more resistance) to attacksofproxy war models. In contrast, its negative effect is when Indonesia cannot control the technology's development so that it will damage the selfidentity of the nation. 3) Indonesia always becomes a target for other countries to launch their proxy warssince Indonesia is considered to have abundantnatural and humanresources but, unfortunately, weak in the quality of the latter one. It is this factor which makes Indonesia a strategic target for the more powerful countries to launch their proxy wars. 4) The dangers of proxy war bring a real threat to Indonesia whichis the decline of the nation's moral as well as bad impacts to the economic sectors. Having such condition will almost ascertain us that it will be more difficult for Indonesia to catch up the development of other countries.

\section{The Preventive Actionsin Facing the Proxy War}

\section{a. The Most Responsible Party in Repressing the Proxy War}

In the perspective of the East Java's PTKIN students, the most responsible partiesto repress the proxy war in Indonesia are: 1) all people especially the government, and 2) the government through its institutions which areconsidered to be the most responsible to take necessary actions so that the proxy war is not widespread. 


\section{b. How to Face the Proxy War}

In the perspective of the East Java's PTKIN students, the government as a state institution is the most responsible partyto anticipate the impact of the dangers of proxy war, therefore, there must be anticipatory measures from the government such as: 1) the government should disseminate or socialize to the public about the dangers of proxy war through seminars and alike, 2) the government must enactregulations that have orientation to protect this country. One of them is to create regulations (laws) that restrict the unimpeded entry of foreign products and people into Indonesia, 3) the government must also restrict / filter internet sites, and 4) in the context of repressing the widespread of proxy war, apart from the government,each individual must fortify themselves with sufficient knowledge that may deepen their spiritual soul (faith) in order to stem the ever-expanding proxy war.

\section{c. Role of Students in Encountering the Proxy War}

In the perspective of the students of the PTKIN in East Java, university students have quite important roles in encountering the proxy war. Their central roles in an attempt to face the proxy war are as follows: 1) Students, considering that they are agents of change in social change of the existing community, basically have an enormous influence in the effort to encounter the proxy war in Indonesia. 2) Unfortunately, even though the students have a great influence, in fact by far they have not done as maximum as possible in controlling the increasingly widespread proxy war. This is becausesome, if not most, students are still apathetic and just think about getting jobs after they graduate. 3) The real action to be taken by students in order to stem the widespread of proxy war isby disseminating to the public about the harmful effects of proxy war. 4) Reckoning that studentsare educated people, a mandate to disseminate the dangers of proxy war to the public is considered to be executable by them. 5) Regarding the students themselves, they also have a contribution to prevent or stem the widespread of proxy war, in which they should be able to think critically and do not accept blindlyany information obtained especially 
those from foreign countries. 6) In an effort to stem the proxy war, the students cannot do it alone in preventing or overcoming its widespread and impacts. 7) It is felt necessary that the students need to cooperate or work hand in hand with state institutions so that any preventive measures taken to encounter the proxy war will be effective. 8) The state institutionsare chosen to be the right partner since they are considered to be the most responsible party and understand the issue of proxy war that is spreading in the community.

\section{Discussion and Data Analysis}

\section{The Perceptions of the East Java's PTKIN Students on Proxy War}

To understand and to assess the East Java's PTKIN students' perceptions on proxy war holistically and comprehensively, the frame of this discussion will be divided into three sub-chapters which are: a) the students' perceptions about the notion of proxy war, b) the danger of proxy war, and c) Indonesia in the constellation of proxy war.

\section{a. The Notion of Proxy War}

Based on the findings of the data obtained from the East Java's PTKIN students, there are at least four views related to the notion of proxy war, namely: first, a proxy war is a war occurring without any direct physical/arms contact but only involving a third party. The purpose of involving a third party is to make it more effective both in strategy and expenses incurred. The examples of such proxy war include drugs, alcohol, a flood of foreign (e.g. Chinese) products, and the LGBT issues. Second, a proxy war is defined as a form of war undertaken not by employing direct physical contacts (arm confrontation), but by using the mass media or technology that is now increasingly flourishing. Third, a proxy war is a form of warfare that does not involve direct physical contacts (arm confrontation), but rather only uses the arguments as a medium. An example of such proxy war is a war of words between artists with their haters. Fourth, a proxy war is understood as a form of a third party's involvement in a particular war with a purpose to end the war quickly.

The students' views on the definition of proxy war is very diverse. There are at least four views which are fundamentally 
different enough when addressing the notion of proxy war. Of those four views,the first twobecome the closest to the definition of proxy war given by Cecily Brewer who defines that a proxy war is "a conflict in which one party fights its adversary via another party rather than engaging that party in direct conflict. ${ }^{15}$

Meanwhile, the Indonesian Army's Chief of Staff General Gatot Nurmantyo defines proxy war as: a confrontation between two great powers by using replacement players to avoid direct confrontation with the reasons for reducing the risk of conflicts resulting in fatal destruction. ${ }^{16}$

From the definitions put forward by Gen. Gatot Nurmantyo, it can be concluded that the proxy war is a war that occurs when an opponent uses a third party instead of fighting each other directly. Governments sometimes used their power as a proxy, whereas nonstate actors more commonly used violence, mercenaries, and other third parties.

Textually, what was raised by the Gatot Nurmantyo is not the same as the understanding of proxy war expressed by those students. However, if we examine both definitions further based on the elements contained in the definition of proxy war expressed by students (i.e. the first two notions) with that of Gatot Nurmantyo, both have the same elements namely: an involvement of a third party, having a particular purpose, a presence of aggrieved party, a presence of facilities / access used and a destruction to the social and cultural order.

Meanwhile, the latter two definitions put forward by those students are still far from the understanding of proxy war expressed both by Gatot Nurmantyo and Brewer. This shows that there are students who still do not understand exactly what is meant by proxy war.

When we refer to the findings of the data that had been mentioned in chapter 4, it shows that the East Java's PTKIN students basically understand what is meant by the notion of war in general. At

15 Brewer, Peril by Proxy ... , p. 138

16 Nurmantyo, "MenghadapiProxy War",JawaPos, 29 March, 2014 
least, according to them, there are some basic understandings about war in general including the following: 1) a war is a dispute involving more than two persons / groups. 2) In a war there must be an effort or actions to defeat one party's opponent. 3) In a war, there will occur attacks done by one party to another with a purpose to defeat its opponent. The effects of this attacking each other will cause losses for both parties. (4) Not all wars must be done by direct physical/arms contacts.

On this last point those students basically justified that a war does not necessarily involve physical contacts (arms confrontation). A war may involve other elements that do not require the disputing parties to confront each other at all. However, even though they agreed that a war does not necessarily involve physical contacts, they did not understand comprehensively what is meant by proxy war. It is quite pity noting that the awareness of the dangers of proxy war begins with the comprehensive understanding about the proxy war itself.

\section{b. The Dangers of Proxy War}

In the view (perspective) of the East Java's PTKIN students, a proxy war has quite dangerous impacts, namely: 1) it can cause a mental damage to the nation's young generation. Eventually the future generation will not be able to take benefits from the natural resources owned by Indonesia, 2) it can also threaten the security and stability of the country (i.e. Indonesia in this case). Having such condition, many new problems will arise and the people will also be deceived, 3) it also has an impact on human rights and economic issues. The freedom of human rights in the countries that become targets of proxy wars are most likely affected, whereas the sectors of economy will suffer a loss or at least be impaired. 4) Apart from the views that acknowledge negative impacts of proxy war, there are students who have a different view about the consequences of proxy war. According to the latter view, the dangers of proxy war cannot be justified simply whether they bring negative or positive impacts but rather they must 
be seen from which point of view. If it causes victims then it may be said that it is dangerous and threatens the lives of many people.

The latter view shows us that some students are still in doubts about the dangers of the proxy war. They only see it as a serious threat if there are visible victims resulted from it. Such view is most likely influenced by their unfamiliarity about the fundamental understanding on what is meant by proxy war.

In fact, in a scientific study carried out by Lembaga Ketahanan Nasional (an Indonesian government institution or the National Resilience Institute, Eng.) held in Jakarta on June 19, 2014, it was stated there that " $a$ superpower state, when pluggingits power by using a proxy war tactic in a particular state, would give a very great detriment impact". Based on their study, the real dangers caused by a proxy war are: 1) Making such state as its foreign market for its product, 2) Inhibiting thebuilding and development of a weaker state's human resources so they cannot compete in a global free market era, 3) Recruiting young people with indoctrination through educational and material facilities, so that they are willing to be their agents. Eventually when they become the future leaders of theirown country, they will be easily controlled by the foreigngovernment, 4) The foreign states will undertake massive investment in strategic industries, in order to dominate strategic industry sectors (oil and gas, mining, electricity, communications, satellite, Military Main Equipment Weapons System, Blue-chip Equity, etc.), 5) Trying to create regional and global free trade pacst, so that local products become supressed and destroyed, as well as penetrating, infiltrating, giving bribes and making collusion with members of the state's legislature so that the strategic legislation products will benefit them, 6) Creating a group/groups of terrorists, so that, - under the pretext of fighting and destroying the global terrorism -, a foreign country can freely and easily intimidate and interveneweaker ones, 7) Purchasing and controlling the mass media, both printed and electronic ones, to shape the public opinion to their favor as well astaking control over highlevel communication technology industries, such as communications 
and reconnaissance satellites, in order to tap and monitor all state's elites' conversations, to monitor and be familiar withthe locations of military power,and to find outboth natural and human resources, and8) Dividing and destroying younger generation of a country with drugs, promiscuity, consumer culture, and indolences. ${ }^{17}$

The impact of a proxy war does not stop quite up there. Not just in the form of physical conflict, in his thesis Woudenberg also explained that a proxy war could also be in the form of aids from richer states to poorer ones. However, rather than giving such aids to help or accelerate the growth of the recipient state's economy, it can also be made as a powerful controlling tool to a particular state. Based on the reason of giving technical assistance and alike, the donor states will always scrutiny the recipient states that receive their flows of money. ${ }^{18}$ Eventually, not only acting as a watchdog, the donor states often becomethe determinant of the direction and development of the recipient ones. This is very dangerous for the future's sustainability of a state because it cannot freely decide the directions of the state's development grand design in accordance with the philosophy it embracesbut rather it must obey and submit to the constraints of the donor states.

\section{c. Indonesia in the Constellation of Proxy War}

In the view of the East Java's PTKIN students, in the constellation of proxy warIndonesia has some important points related to its position and roles as a country. , namely: 1) Indonesia has entered into a proxy war since the Dutch colonial era. It was marked with various indications such as the entry of foreign cultures to Indonesia that eliminate the identity of this nation. The increasingly widespread drug trafficking and the latest case of the widespread LGBT issues that deprave the morals of this nation are also real facts that cannot be refuted. 2) Relating to the position of Indonesia in the constellation of proxy war, there are several views, which are: first, Indonesia isthe

17 the Indonesian National Resilience Institute (Lembaga Ketahanan Nasional), Jakarta, 19June, 2014

18 Ibid. 
most disadvantaged country since the Indonesian people will be controlled and much influenced by foreigners without being able to think critically. Second, in addressing the position of Indonesia in the constellation of proxy war, there are two effects, - positive and negative ones -, faced by Indonesia. Its positive effect is that Indonesia will be able to keep abreast of the era's development so that it will be more alert (more resistance) to attacksofproxy war models. In contrast, its negative effect is when Indonesia cannot controlthe technology's development so that it will damage the self-identity of the nation. 3) Indonesia always becomes a target for other countries to launch their proxy warssince Indonesia is considered to have abundantnatural and humanresources but, unfortunately, weak in the quality of the latter one. It is this factor which makes Indonesia a strategic target for the more powerful countries to launch their proxy wars. 4) The dangers of proxy war bring a real threat to Indonesia whichis the decline of the nation's moral as well as bad impacts to the economic sectors. Having such condition will almost ascertain us that it will be more difficult for Indonesia to catch up the development of other countries.

The indications that Indonesia has been imprisoned for a long time in a proxy war can be seen from the increasing number of foreigners entering Indonesia, the issues of LGBT, drugs, alcohol and many others as mentioned by Gatot Nurmantyo when explaining the dangers of proxy war. ${ }^{19}$ It is not a mere figment that Indonesia has always been a target of a proxy war by other countries. Such is because Indonesia has the potential of abundant natural and human resources. But the problem is that the quality of our human resources is still very low. It can be seen from the number of population and the development of economy which is not in line with the progress of the level of education in this country. ${ }^{20}$

\footnotetext{
19 Read further about the characteristics of proxy war attacks by another state described by Nurmantyo, "MenghadapiProxy War", JawaPos, 29 March, 2014

20 The worrying rank of education quality in Indonesia maybe read on: http://log.viva.co.id/news/read/696306-ranking-pendidikan-dunia-tahun-2015--indonesia-keberapa-
} 
Meanwhile, regarding to its position in the constellation of proxy war as mentioned by the East Java's PTKIN students, they stated that Indonesia also gets benefits or advantages from the proxy war. One advantage is that Indonesia will be more alert and will establish a special institution to anticipate it. However, what was proposed by those students contradicts to the concept of proxy war as explained by Gatot Nurmantyo. According to him,a proxy war is difficult to detect because the mission in a proxy war model is intended to make enemies not realize that they are actually the object of a war. ${ }^{21}$ Therefore, by observing to the facts that exist today, what was proposed by the students that Indonesia became the beneficiaries of a proxy war isnot quite right.

\section{The Preventive Actions of the East Java's PTKIN Students to Encounter the Proxy War}

In order to understand and to assess the East Java's PTKIN students' perceptions about their preventive actions to face the proxy war comprehensively, the frame of this discussion will be divided into three subchapters which are:

\section{a. The Most Responsible Party to Repress the Proxy War}

In their view, the most responsible partiesto repress the proxy war in Indonesia are all people especially the government. This is so based on the reason that the government through its institutions is considered to be the most responsible party to take necessary actions so that the proxy war is not widespread.

The emphasis on the government as the party liable to stem the increasingly widespread proxy war indicates that the student justify themselves not to have an important role and a great responsibility on the prevention of proxy war from spreading. Yet, we know and it is almost agreed by all that the students are moral force agents in the life of the nation, state and society more than other components of a society. Even in the era of Indonesian reform, their popularity as moral enforcers was put align with the religious scholars and teachers. Furthermore, after the reform era, the general awareness of students as agents of change, a moral

\footnotetext{
${ }^{21}$ Read further: Nurmantyo, "Menghadapi Proxy War", JawaPos, 29 March, 2014
} 
force, and an intellectual force has increased very remarkably.22 In accordance with their role, both for society and for the sustainability of this nation, then, an important and the most responsible element to stem the ever-expanding proxy war should properly be the students themselves. Therefore they appropriately have independent awareness and responsibility as a logical consequence of the academic degree (and knowledge) they possess, and, with full consciousness, they should position themselves as the bearer of responsibility so that Indonesia can be free and immune from any attack of proxy warswhich are becoming massive.

Seeing such condition of our students, it becomes a chore that must be worked out by all of us. The students who are known as the agents of change and agents of control seem to have lost their identity and their sense of nationalism is fading. It certainly should not be neglected considering that theyare the generations who will determine the future of this nation.

\section{b. The Ways to Encounter the Proxy War}

In their view, the government as a state institution is the most responsible partyto anticipate the impact of the dangers of proxy war, therefore, there must be anticipatory measures from the government such as: 1) the government should disseminate or socialize to the public about the dangers of proxy war through seminars and alike, 2) the government must enactregulations that have orientation to protect this country. One of them is to create regulations (laws) that restrict the unimpeded entry of foreign products and people into Indonesia, 3) the government must also restrict / filter internet sites, and 4) in the context of repressing the widespread of proxy war, apart from the government, each individual must fortify themselves with sufficient knowledge that may deepen their spiritual soul (faith) in order to stem the ever-expanding proxy war.

From this view,it is clearer and more convincing that the students of PTKIN in East Java deemed the government to bethe partywho has an important role to stem the ever-expanding proxy war. They proposed the

\footnotetext{
22 SyahrinHarahap, Penegakan Moral Akademik di Dalam dan di Luar Kampus, Jakarta: Rajawali Press, 2005, p.193
} 
governmentto socialize the dangers of proxy war and to create pro people's sovereignty policies (regulations). Once again they did not place themselves as the most essential element in encountering the proxy war.

If this condition is not dealt with appropriately, it would cause a great concern and a very tremendeous threat to the survival of the nation's future. Such is as expressed by Syahrin Harahap, he explained that the students as the most potential human resources for a nation are a real and vital asset and have special characteristics not shared by other community groups. The students are the strength of a nation's development as well as an opening key for the realization of a better future as we aspire. ${ }^{23}$

\section{c. The Roles of Students in Facing the Proxy War}

In the view of the East Java's PTKIN students, when they were questioned about their roles in facing the proxy war, they agreed to an answer that they have a very important role in it. However, despite having such role in the effort to stem the wide spreading of the proxy war, they acknowledged that they have not undertaken it as maximum as expected by many. This is because they thought that there were still many students nowadays who are apathetic and are more oriented and focused towards pursuing a career after graduating from universities.

The real action to be taken by the students in an effort to stem the widespread of the proxy war is by disseminating to the public about its harmful effects. Reckoning that they are educated people, such mandate is considered to be executable by them.

Meanwhile, regarding the students themselves, they also have a contribution to prevent or stem the widespread of proxy war, in which they should be able to think critically and do not accept blindlyany information obtained especially those from foreign countries. Such an attitude has to be owned by them noting that they must really be ready to face the challenges of globalization, both in the present and future eras. This is so because, whether they realize it or not, there will be many

${ }^{23}$ Ibid. 
challenges to be encountered by them such as consumerism, materialism, secularism, dissipation practices and others. ${ }^{24}$

In addition, the students are also aware that, in dealing with the proxy war, they cannot work alone in tackling or preventing the widespread of its impacts. They feel the need to cooperate and work hand in hand with state institutions so that any preventive measure taken can be effective.The state institutionsare chosen to be the right partner since they are considered to be the most responsible party and understand the issue of proxy war which is spreading in the community.

In a bid to prevent the impacts of proxy war from spreading, the students put themselves to disseminate its harmful effects, to be critical of globalization and to cooperate with the government.However, they should not forget that they are agents of control that should give a continuous control to the present government. This is so noting that the proxy war always utilizes existing proxies to impair a state so much so that it is possible that some of the state institutions or policies issued by the government actually even pave the way for the proxy war to come into action in this country. That is the moment when the students must be critical and exercise their role as the agents of control against the arbitrariness of the government that is not pro-people's sovereignty. ${ }^{25} \mathrm{i}$

Furthermore, the students must also be 'open'.In an effort to prevent the proxy war from spreading, it does not only require the cooperation with the institutions/agencies of government but alsoshould involve all elements of society to work hand in hand in encounteringits attacks. This is so because not only a specific part of community but all people can become the target of this model of an inhumanwar.

\section{E. Conclusion}

From this study it can be concluded that the weak knowledge of the East Java's PTKIN students on the understanding of proxy war can be fatal for the nation's future. Some of those students assumed that a proxy war has a positive aspect because they believe that with its presence, Indonesia can establish an

\footnotetext{
${ }^{24}$ Sunarso, M.Si, et al., Pendidikan Kewarga negaraan (PKn) untuk Perguruan Tinggi,UNY Press, 2007, p. 45

${ }^{25}$ To understand the meaning of the function of agent of control that is embedded onto university students, see: Syahrin Harahap. Penegakan Moral Akademik ...,p.193
} 
institution as a precaution against it.But, it contradictswith the concept of proxy war in which the state that launches it always tries to make its opponents not realize that they serve as the object of attacks of the proxy war.The studentsalso viewed that regarding to the preventive action to encounter the proxy war, the most responsibleparty to stem its widespread is the government. It is quite a pity considering that they did not place themselves as an important element in stemming the proxy warwhereas they bear a duty as agents of change, agents of control and iron stock.

Seeing such conditions, there must therefore be a serious effort both from the government and students through their own awareness to deal with the proxy war threats based on the assumption that: students as agents of change, agents of control and iron stock should position themselves as frontliners in the process of building and directingthe motion of this nation. Whatever problem encountered by the Indonesian people should also become a serious problem and priority for them. Students should be more open to cooperate with non-government institutionsand do not suffice themselves to cooperateonly with the government'sones, especially in facing the proxy war.The PTKIN in East Java as educational institutions should improve and foster a sense of nationalism to their students through their standard curriculum and/or extra-curricular activities.This is important noting that the sense of nationalism is the first key to form cadres of students who are responsive to sensitive issues concerning the sovereignty of the nation. The government must improve the quality of education as an effort to fortify its people against the dangers of proxy war. 


\section{Bibliography}

Abbink, Jon. 2003. Ethiopia-Eritrea: Proxy Wars and Prospects of Peace in the Horn of Africa. Journal ofContemporary African Studies 21, 3 September.

Bagus, Lorens. 1996.KamusFilsafat. Jakarta: Gramedia.

Beyer, B. K.1995.Critical Thinking.Bloomimgton, IN: Phi Delta Kappa Educational Foundation.

Brewer, Cecily. 2011. Peril by Proxy: Negotiating Conflicts in East Africa.International Negotiation 16, 137-167.

Byman, Daniel, et al.2001.Trends in Outside Support for Insurgent Movements. Santa Monica: RAND.

Ciardiello, A.V. 2004.Democracy's YoungHeroes: An Instructional Model of CriticalLiteracy Practices, Reading Teacher, 58(2),138-147.

Clausewitz, Carl Von. 1986. On War.Trans. and ed. Makmur Supriyatno titled Buku Tentang Perang. Jakarta: Yayasan Prajurit.

Cleary, Paul. 2007. Shake Down: Australia's Grab for Timor Oil. Australia: Allen and Unwin Publishing.

Freebody, P. 2008. Critical literacy education: On living with 'innocent language'. In Street BV, Hornberger NH (Eds.).Encyclopedia of language and education.Vol. 2 107-119. Heidelberg, Germany: Springer.

Harahap, Syahrin.2005. Penegakan Moral Akademik di Dalam dan di Luar Kampus. Jakarta: Rajawali Press.

Hartaji, DamarA. 2012. Motivasi Berprestasi pada Mahasiswa yang Berkuliah dengan Jurusan Pilihan Orang Tua.Jakarta: Fakultas Psikologi Universitas Gunadarma.

Hedge, A. 2007.Thermal Sensation and thermoregulation. Cornell University: DEA350 Human Factors, Ambient Environment.

http://log.viva.co.id/news/read/696306-ranking-pendidikan-dunia-tahun-2015-indonesia-ke-berapa-(Accessed 2016-10-12)

Lievrouw, Leah A. and Livingstone,Sonia. 2006. TheHandbook of New Media, Los Angeles, London, New Delhi, Singapore, Washington DC: SAGE Publications Ltd.

Loveman, Chris. 2002. Assessing the phenomeon of proxy intervention. Journal of Conflict, Security and Development.Issue 2-3, Routledge.

Melander, Erik., Öberg, Magnus., and Hall,Jonathan. 2009.Are 'new wars' more atrocious? Battle severity, civilians killed and forced migration before and after the end of the Cold War.European Journal of International Relations, 15(3).SAGE Publication and ECPR. 
Nasution. A. H. 1953.Pokok-Pokok Perang Gerilya dan Pertahanan RI di Masa Lalu dan Masa yang Akan Datang.Jakarta: Bagian Penerbitan Buku Ketentaraan.

Nazir, Moh. 1999. Metode Penelitian. Jakarta: Ghalia Indonesia.

Nurmantyo, Lt. Gen. Gatot.asThe Chief of the Indonesian Army's Strategic Reserve Command. 2014. Menghadapi Proxy War.JawaPos, 29 March.

Nurrachman. 2016.IAIN students Tulungagung Department of Family Law (HK) semesters VII on July 2.

Poerwadarminta.1976.Kamus Besar Bahasa Indonesia. Jakarta: Balai Pustaka.

Satori, Djam'an and Komariyah, Aan. 2009.Metodologi Penelitian Kualitatif. Bandung: Alfabeta.

Sugiono, 2008.Metode Penelitian Kuantitatif dan R\&D. Bandung: Alfabeta.

Sunarso, M.Si., et al. 2007. Pendidikan Kewarganegaraan (PKn) untuk Perguruan Tinggi. Yogyakarta: UNY Press.

Suryohadiprojo, Sayidiman. 1987.Manusia dan Masyarakat Jepang. Jakarta: Universitas Indonesia.

Tanzeh, Ahmad and Suyitno.2006.Dasar-dasar Penelitian. Surabaya: Elkaf.

The British Petroleum. 2013.BP Statistical Review of World Energy.Uckfield, UK: Pure Print Group Ltd.

The Indonesian National Resilience Institute (Lembaga Ketahanan Nasional) . 2014.The results of the scientific discussion, June $19^{\text {th }}$.Jakarta.

Widjaja, William Tanu. 2009. 101 Inti Sari Perang SunTzu.Yogyakarta: Med Press.

Woudenberg, JMR. 2011. Used or abused? Armed non-state actors as proxies. Master thesis. Master Politicologie, Internationale Betrekkingen, International Military Security. 